\title{
Regarding Journal of Thoracic Disease Vol 12, Supplement 1 (February 2020) (Sepsis: Science and Fiction)-Driving blind: instituting SEP-1 without high quality outcomes data
}

\author{
Sean R. Townsend ${ }^{1,2}$ \\ ${ }^{1}$ Division of Pulmonary, Critical Care Medicine, California Pacific Medical Center, San Francisco, CA, USA; ${ }^{2}$ Department of Medicine, University \\ of California San Francisco School of Medicine, San Francisco, CA, USA \\ Correspondence to: Sean R. Townsend, MD. California Pacific Medical Center, 11th Floor, Executive Administration, 1101 Van Ness Avenue, San \\ Francisco, CA 94109, USA. Email: townsesr@sutterhealth.org. \\ Comment on: Wang J, Strich JR, Applefeld WN, et al. Driving blind: instituting SEP-1 without high quality outcomes data. J Thorac Dis \\ 2020;12:S22-36.
}

Submitted May 19, 2021. Accepted for publication Jun 02, 2021.

doi: 10.21037/jtd-2021-29

View this article at: http://dx.doi.org/10.21037/jtd-2021-29

I read with interest the recent article by Wang et al. "Driving blind: instituting SEP-1 without high quality outcomes data," in the Fournal of Thoracic Disease Vol 12, Supplement 1, February 2020 (1).

The article, in part, addressed potential conflicts of interest regarding SEP-1, a quality of care performance measure sponsored by the United States Centers for Medicare and Medicaid Services. I am concerned that this article was not subject to peer-review, having been submitted December 14, 2019 and accepted for publication December 20, 2019. Dr. Paul Marik was guest editor of this supplemental issue of the Fournal of Thoracic Diseases. The International Committee of Medical Journal Editors (ICJME) states that, "editors who make final decisions about manuscripts should recuse themselves from editorial decisions if they have conflicts of interest or relationships that pose potential conflicts related to articles under consideration.” (2). The ICJME makes it clear that conflicts may be due to "...personal relationships or rivalries, academic competition, and intellectual beliefs." (2). Dr. Marik should have recused himself from reviewing the piece by Wang et al. due to conflicts of interest having published highly critical remarks about SEP-1 $(3,4)$. These intellectual conflicts of interest partly weaken the credibility of the article by Wang et al.

\section{Editor's note}

After several rounds of back and forth discussion by the editorial office, the above-mentioned disagreement has been resolved and a consensus has been reached among the authors of the concerned article titled "Driving blind: instituting SEP-1 without high quality outcomes data," the Guest Editor and Dr. Sean R. Townsend by publishing an erratum of the concerned article based on the matter of fact.

Fournal of Thoracic Disease (FTD) endorses the following core values to advance its vision and mission: Integrity, Innovation, Internationalism, Credibility, Professionalism, Service. We seek to ensure that everyone within the editorial process feels valued: guest editors, reviewers, the authors, and of course, we value the readers' feedback.

We strive to keep $\mathcal{F T D}$ in conformity with the Committee on Publication Ethics (COPE) guidelines and the ICMJE's Recommendations. We appreciate the efforts from authors, guest editors, readers to maintain the high quality of $\mathcal{F T D}$, and together we aim to make the editorial process a positive publishing experience.

\section{Acknowledgments}

Funding: None.

\section{Footnote}

Provenance and Peer Review: This article was a standard submission to the journal. The article did not undergo external peer review. 
Conflicts of Interest: The author has completed the ICMJE uniform disclosure form (available at http://dx.doi. org/10.21037/jtd-2021-29). The author has no conflicts of interest to declare.

Ethical Statement: The author is accountable for all aspects of the work in ensuring that questions related to the accuracy or integrity of any part of the work are appropriately investigated and resolved.

Open Access Statement: This is an Open Access article distributed in accordance with the Creative Commons Attribution-NonCommercial-NoDerivs 4.0 International License (CC BY-NC-ND 4.0), which permits the noncommercial replication and distribution of the article with the strict proviso that no changes or edits are made and the original work is properly cited (including links to both the formal publication through the relevant DOI and the license).
See: https://creativecommons.org/licenses/by-nc-nd/4.0/.

\section{References}

1. Wang J, Strich JR, Applefeld WN, et al. Driving blind: instituting SEP-1 without high quality outcomes data. J Thorac Dis 2020;12:S22-36.

2. The International Committee of Medical Journal Editors, Recommendations for the Conduct, Reporting, Editing, and Publication of Scholarly Work in Medical Journals, Dec. 2019, Section II B 1 c and Section II B. pp. 3-4. Accessed May 21, 2021. Available online: http://www. icmje.org/icmje-recommendations.pdf

3. Marik PE, Malbrain MLNG. The SEP-1 quality mandate may be harmful: How to drown a patient with $30 \mathrm{~mL}$ per $\mathrm{kg}$ fluid! Anaesthesiol Intensive Ther 2017;49:323-8.

4. Marik PE. SEP-1: The Lactate Myth and Other Fairytales. Crit Care Med 2018;46:1689-90.
Cite this article as: Townsend SR. Regarding Fournal of Thoracic Disease Vol 12, Supplement 1 (February 2020) (Sepsis: Science and Fiction) - Driving blind: instituting SEP-1 without high quality outcomes data. J Thorac Dis 2021;13(6):39303931. doi: 10.21037/jtd-2021-29 